\title{
TRANSFORMASI ENTREPRENEUR SYARIAH DI ERA INDUSTRI 4.0
}

\author{
Maryati Mallongi \\ Universitas Muslim Indonesia \\ Email: mallongimaryati@gmail.com
}

Entrepreneur merupakan istilah yang dipadankan dengan kewirausahaan. Konsep ini merupakan suatu aktivitas usaha yang dilakukan secara mandiri menggunakan sumber daya kecerdasan bisnis dalam menciptakan peluang usaha untuk mencapai keuntungan. Secara esensial, entrepreneur syariah dapat dimaknai sebagai aktivitas usaha yang menerapkan nilai-nilai Islam di dalamnya. Penulisan ini bertujuan menguraikan konsep entrepreneur syariah dan transformasinya di era industri 4.0. Pembahasan dalam penulisan ini merupakan telaah pustaka yang dilakukan untuk memenuhi kebutuhan literasi entrepreneurship. Berdasarkan hasil kajian dapat disimpulkan bahwa era industri 4.0 mendorong transformasi entrepreneur lebih moderen. Ciri tranformasi tersebut dapat dilihat pada aspek inovasi konsep pemasaran, kecepatan koneksi teknologi, ekonomi pasar bebas, peluang otomatisasi, dan kemudahan dan efisiensi. Bentuk transformasi tersebut ke erah yang lebih cepat dan masif, sehingga seorang entrepreneur harus melakukan penguatan manajemen dan strategi dalam pengelolaan bisnis.

Kata Kunci: Transformasi, Entrepreneur Syariah, Industri 4.0

\section{A. Pedahuluan}

Kemajuan teknologi mendorong pertumbuhan sektor usaha dengan begitu cepat dan masif. Dunia bisnis entrepreneur sebagai salah satu sektor bisnis juga dituntut untuk meningkatkan kinerja pelayanan konsumen secara canggih menggunakan teknologi informasi. Saat ini, realitas menunjukkan bahwa berbagai lembaga bisnis sangat bergantung pada teknologi yang berkembang. Arus besar ini tidak bisa dihindari, sehingga seluruh pelaku usaha harus beradaptasi.

Tantangan di bidang entrepreneur semakin terasa memasuki era revolusi Industri 4.0. Perkembangan industri manufaktur yang beralih menggunakan jasa robotik dan kekuatan data yang tersimpan berbasis teknologi menjadi ancaman tersendiri bagi eksistensi umat manusia. Karakteristik revolusi industri 4.0 mengintegrasi internet dan teknologi pada suatu perusahaan jasa wirausaha. Istilah industri 4.0 ini pertama kali diperkenalkan oleh berbagai kelompok di Jerman untuk peningkatan daya saing di bidang industri. Pemerintah Jerman kemudian 
mengadopsi gagasan cemerlang ini sebagai suatu program strategi teknologi tinggi yang harus terwujudkan pada tahun 2020 .

Saat ini, seluruh umat manusia telah berada pada tahun 2020 sebagai titik puncak target maksimalisasi program teknologi Jerman tersebut. Fakta menunjukkan bahwa visi program tersebut bukan diskursus semata karena hal tersebut saat ini terealisasi mendorong seluruh negara di dunia meredefenisi sistem informasi dan teknologi yang dimiliki selama ini. Sektor entrepreneur juga harus menginovasi diri dengan cepat menggunakan internet dan teknologi yang berkembang.

Revolusi Industri 4.0 dapat dipahami sebagai suatu kemajuan terjadinya transformasi secara berkesinambungan informasi, proses layanan, sistem produksi, kerja sama, yang terkoneksi secara cepat menggunakan teknologi. Seluruh sistem manufaktur maupun organisasi sosial politik dan bisnis terkoneksi dengan cepat. Transformasi ini melahirkan berbagai prototipe digitalisasi seperti; bank data dan informasi, Internet of Things (IoT), robotika, dan kecerdasan buatan kemudian melahirkan istilah keren lainnya sepertil; smart industry (industri pintar), intelligent industry (industri cerdas), smart factory (pabrik pintar), smart manufacturing (manufaktur cerdas).

Ledakan kemajuan besar yang terjadi harus dimanfaatkan oleh dunia entrepreneur (wirausaha) syariah. Kecanggihan teknologi informasi saat ini haruslah dimanfaatkan sepenuhnya untuk memaksimalkan pelayanan kepada berbagai konsumen. Dengan demikian, sektor entreprenur syariah akan tertransformasi dengan cepat mempraktekkan nilai pijakan syariahnya. Saat ini, entrepreneur syariah memasuki babak baru digitalisasi. Setiap muslim dapat melakukan wirausaha secara terkoneksi dengan teknologi sehingga proses transaksinya cepat. Di sisi lain, ukhuwah islam juga terjalin dengan begitu masif melampui jarak salaman dan perkenalan. Di internet juga berkembang entrepreur berbasis youtuber dengan konten yang beragam tentang musim religi, kajian dan ceramah agama, hingga gaya hidup hijab.

Ragam transformasi tersebut mendorong penulis tertarik melakukan kajian dengan judul; "Transformasi Entrepreneur Syariah di Era Industri 4.0." Tujuan penulisan ini untuk merumuskan bentuk-bentuk transformasi entrepreneur syariah di era industri 4.0. Pendekatan kajian yang digunakan adalah studi pustaka yakni 
model kajian menggunakan berbagai akses informasi pada literatur yang tersedia dalam bentuk buku, jurnal, maupun bahan-bahan literatur digital.

\section{B. Pembahasan}

\subsection{Hakikat Entrepreneur}

Entrepeneur merupakan salah satu istilah menarik yang akhir-akhir ini dilekatkan pada pegiat wirausaha. Istilah ini merupakan padanan dari kata kewirausahaan. Suryana dan Bayu (2010: 24) menjelaskan bahwa istilah entrepreneurship berawal dari bahwa Prancis, entreprende yang berarti petualang, pencipta, dan pengelolah usaha. Richard Cantillon pertama kali memperkenalkan istilah ini pada tahun 1755. Seiring perkembangan, istilah ini semakin populer setelah digunakan pakar ekonomi J.B Say pada tahun 1803 untuk memberikan narasi pada pengusaha yang sanggup memindahkan sumber daya ekonomi dari tingkay produktivitas rendah ke tingkat lebih tinggi.

Abdullah (2011: 1) mengemukakan bahwa kata wirausaha yang dipadankan dengan kata entrepreneur atau ada juga yang memadankannya dengan kata wiraswasta memang memiliki perbedaan tertentu namun tidak terlalu signifikan. Lebih lenjut dijelaskan bahwa, wirausaha adalah orang yang berani membuka lapangan pekerjaan dengan kekutan sendiri, tetapi juga menguntungkan masyarakat, karena dapat menyerap tenaga kerja yang memerlukan pekerjaan.

Kasmir (2006: 16) memberikan penjelasan entrepreneur sebagai orang berjiwa berani mengambil resiko pembukaan usaha. Jiwa berani mengambil resiko merupakan suatu mental mandiri memulai suatu usaha tanpa takut atau cemas sekalipun dalam ketidakpastian. Kegiatan wirausaha dapat dilakukan sendiri atau secara berkelompok. Seseorang yang berwirausaha atau menjadi entrepreneur harus selalu berusaha mencari, memanfaatkan, dan menciptakan peluang usaha yang dapat memberikan keuntungan.

Berdasarkan penjelasan tersebut, dapat dikemukakan bahwa istilah entrepreneur merupakan istilah yang merujuk pada individu yang memulai suatu langkah pembuakaan lapangan kerja melalui rintisan aset usaha secara mandiri yang menguntungkan amsyarakat karena efek serapan tenaga kerja yang diperlukan banyak orang. Defenisi yang telah dikemukakan di atas pula menunjukkan 
karakteristik setiap orang yang berani mengambil berbagai peluang usaha dan resiko kerugian yang ditimbulkannya sebagai suatu gejala alami dalam berusaha.

\subsection{Manfaat Entrepreneur}

Entrepreneur merupakan kegiatan yang bermanfaat secara ekonomi dan sosial. Selain memberikan keuntungan pada pelakunya, kegiatan ini juga dapat membantu orang lain meningkatkan taraf hidup secara ekonomis. Beberapa pakar mengemukakan manfaat entrepreneur sebagai berikut.

Basrowi (2011: 7) mengemukakan bahwa berdasarkan beberapa penelitian menunjukkan bisnis mikro, kecil dan menengah mendorong kecenderungan bekerja lebih keras untuk menghasilkan uang lebih banyak. Hal ini membanggakan daripada bekerja di suatu perusahaan besar. Setiap calon wirausahawan sebaiknya mempertimbangkan manfaat bisnis mikro, kecil dan menangan sebelum mendirikan usaha.

Selanjutnya Zimmerer (2005: 8) merumuskan manfaat entrepreneur atau kewirausahaan, sebagai berikut.

1) Berpeluang dan kebebasan mengendalikan nasib sendiri

Dengan demikian, menjadi entrepreneur merupakan suatu peluan mencapai hidup yang diinginkan. Seseorang yang berwirausaha akan selalu mencoba memenangkan hidup serta memungkinkan untuk menjadikan lahan bisnisnya untuk mencapai cita-cita yang diinginkan.

2) Memberi peluang melakukan perubahan

Peningkatan jumlah entrepreneur menangkap peluang akan mampu melahirkan peluang perubahan. Proses mendorong perubahan ini sangat penting untuk menyeimbangkan kepedulian terhadap masalah ekonomi dan sosial di lingkungan masyarakat untuk mendorong kehidupan yang lebih baik lagi.

3) Memberi peluang untuk mencapai potensi diri sepenuhnya

Bekerja di suatu perusahaan besar terkadang menjenuhkan dan kurang menantang, sehingga tidak memiliki daya tarik. Bagi seorang yang berjiwa entrepreneur tidak ada perbedaan antara bekerja dan menyalurkan hobi, keduanya sama saja, bahkan dalam dunia bisnis. Bisnis bagi seorang wirausahawan merupakan instrumen aktualisasi diri. Oleh karena itu, keberhasilan berwirausaha 
merupakan suatu hal yang ditentukan oleh kreativitas, antusiasme, inovasi, dan visi secara mandiri.

4) Berpeluang untuk meraih keuntungan seoptimal mungkin

Keuntungan merupakan motivasi penting mendirikan usaha. Lebih lanjut dijelaskan bahwa berdasarkan hasil penelitian Thomas Stanley dan William Danko berkesimpulan bahwa pemilik perusahaan sendiri mencapai dua pertiga dari jutawan Amerika Serikat. Setiap orang yang bekerja memiliki perusahaan sendiri empat kali lebih besar peluangnya untuk menjadi jutawan daripada orang-orang yang bekerja untuk orang lain atau menjadi karyawan perusahaan lain.

5) Berpeluang untuk berperan aktif dalam masyarakat dan mendapatkan pengakuan atas usahanya

Meskipun menjadi pengusaha kecil, namun tetap dihargai dan paling dipercaya. Peranan penting yang dimainkan dalam sistem bisnis di lingkungan setempat membentuk kesadaran bahwa kerja memiliki dampak nyata melancarkan fungsi sosial ekonomi.

6) Berpeluang melakukan sesuatu yang disukai dan menumbuhkan rasa senang dalam mengerjakannya

Usaha sekecil apapun memiliki daya tarik kesukaan yang mengundang seseorang masuk ke dalamnya. Dengan demikian berwirausaha merupakan hobi tertentu dalam dunia bisnis. Untuk itu pekerjaan yang dilakukan merupakan penyaluran hobi. Hal yang menjadi penghargaan bagi pebisnis atau wirausahawan bukanlah tujuannya, melainkan lebih pada proses dan perjalanannya.

Berdasarkan penjelasan tersebut di atas, dapat disimpulkan bahwa entrepreneur atau wirausaha merupakan sektor produktif yang sangat bermanfaat secara ekonomis, sosial, karir, dan proses pengalamannya. Bidang ini membuat seseorang mengendalikan nasibnya sendiri serta memberikan peluang bagi seseorang menyalurkan seluruh potensinya. Peluang yang terbuka di bidang entrepreneur memberikan keungtungan yang optimal, dan dari keuntungan ini dapat meningkatkan status sosial seorang pebisnis. Hal bermakna menggeluti entrepreneur ada pada rasa kesenangan menekuninya untuk mengapai tujuan proses pengalaman yang berharga.

\subsection{Konsep Entrepreneur dalam Islam}


Entrepreneur dalam Islam dikelompokkan dalam masalah muamalah. Konsep yang berkaitan dengan masalah muamalah berhubungan dengan relasi yang bersifat horizontal manusia. Seluruh prosesnya dipertanggungjawabkan kelak di akhirat. Hal ini sebagaimana difirmankan Allah Swt, sebagai berikut.

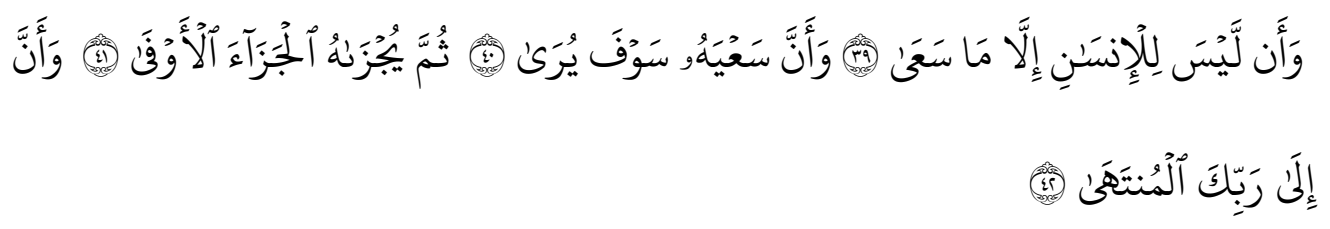

Terjemahannya: dan bahwasanya seorang manusia tiada memperoleh selain apa yang telah diusahakannya, dan bahwasanya usaha itu kelak akan diperlihatkan (kepadanya), kemudian akan diberi balasan kepadanya dengan balasan yang paling sempurna dan bahwasanya kepada Tuhanmulah kesudahan (segala sesuatu) (QS. An-Najm [53]: 39-42)

Seorang entrepreneur hendaknya memerhatikan tatanan muamalah yang digariskan dalam Islam. Seluruh norma etis yang terumuskan dalam Islam sejak zaman Rasulullah memberikan manfaat yang sangat bernilai bagi normalnya siklus perdagangan. Misalnya dalam mengembangkan jual beli hendaknya menghindari riba dan tidak boleh mengambil dan memakan harta orang lain dengan cara batil dalam perdagangan. Hal ini jelas merupakan sesuatu yang dilarang oleh Allah Swt. Hal ini ditegaskan oleh Allah dalam firmannya sebagai berikut.

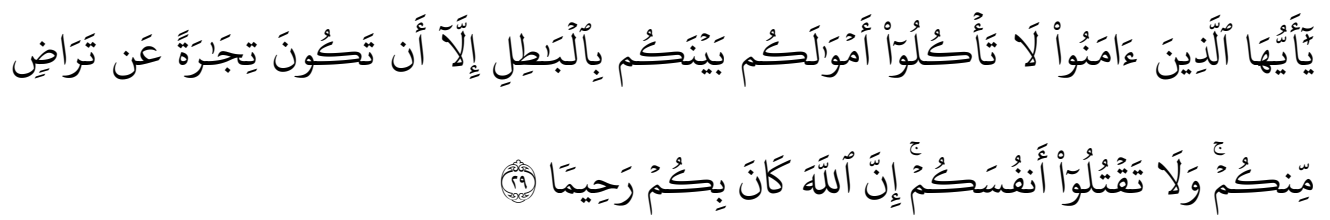

Terjemahannya: Hai orang-orang yang beriman, janganlah kamu saling memakan harta sesamamu dengan jalan yang batil, kecuali dengan jalan perniagaan yang berlaku dengan suka sama-suka di antara kamu. Dan janganlah kamu membunuh dirimu; sesungguhnya Allah adalah Maha Penyayang kepadamu (QS. An Nisa [4]: 29)

Ayat-ayat tersebut menunjukkan bahwa dalam menjadi entrepreneur seseorang dituntut tidak hanya memiliki kecakapan berbisnis dalam hal kalkulasi keuntungan semata, namun harus memiliki moralitas yang menjamin berlangsungnya proses 
pengembangan bisnis secara adil dan membawa berkah bagi orang lain sebagai mitra. Moralitas ini akan menjauhkan seorang entrepreneur dari hal-hal subhat seperti riba serta menjadikannya sebagai sosok entrepreneur yang adil dengan akhlak yang terpuji. Moralitas ini sangat penting di tengah kemajuan teknologi yang mendorong entrepreneur melakukan transaksi melalui jejaring media sosial. Saat ini banyak model bisnis yang konvensional telah beralih menggunakan kemajuan teknologi yang tersedia sehingga mendorong perdagangan dilakukan tanpa harus bertemu langsung dengan konsumen.

\subsection{Transformasi Entrepreneur Syariah Era Industri 4.0}

Entrepreneur syariah menerapkan nilai-nilai ajaran Islam dalam seluruh aspek pengelolaan bisnis yang dikembangkan. Penerapan nilai-nilai Islam ini dilakukan secara komprehensif karena bersifat universal karena seluruh prinsip muamalah dalam Islam dapat diterapkan oleh siapa saja, dalam artian tidak hanya terbatas dalam lingkungan masyarakat muslim saja.

Perlu dipahami bahwa entrepreneur syariah memiliki karakteristik tersendiri yang dapat dikenali secara khas. Karakteristik ini antara lain; dalam pelaksanaannya selalu berpijak pada nilai-nilai ajaran Islam, memiliki pemahaman terhadap batasan halal dan haram dalam dunia bisnis, dan berorientasi pada kemaslahatan dunia dan akhirat. Karakteristik ini akan melekat pada diri seorang entrepreneur muslim. Tidak tertutup kemungkinan masyarakat di luar Islam juga mengadopsi hal ini untuk mencapai kemaslahatan di dunia.

Pijakan nilai Islam dalam entrepreneur sangat penting menjaga keseimbangan wirausaha yang dilakukan di era industri 4.0. Banyak jenis usaha diuntungkan dengan kemajuan teknologi informasi. Misalnya, seseorang yang ingin menjadi pebisnis tidak perlu menghabiskan dana membangun toko, saat ini cukup memiliki sebuah telepon genggam android dapat berfungsi sebagai toko digital yang memudahkan seseorang melakukan promosi dan transaksi. Dalam promosi dan transaksi di dunia digital saat ini sangat rentan dengan berbagai kecenderungan penipuan. Oleh karena itu, pegangan pada seluruh nilai Islam menjamin seseorang bersikap amanah dan adil dalam menjalankan seluruh model bisnis.

Terdapat beberapa ciri transformasi entrepreneur syariah era industri 4.0, yang berbeda dengan konsep wirausaha konvensional. Ciri wirausaha konfensional 
dilakukan secara langsung. Pembeli dapat melihat produk secara langsung. Umumnya wirausaha bisnis konvensional memiliki kios sendiri sehingga pembeli dapat mengunjungi kios. Saat ini, bisnis dengan ciri konvensional masih bisa ditemukan, namun tampil lebih moderen. Wirausaha bisnis konvensional telah berubah mengikuti perkembangan teknologi yang berkembang.

Perkembangan teknologi mutakhir era industri 4.0 saat ini telah mendorong transformasi bidang wirausaha (entrepreneur). Beberapa transformasi dapat diuraikan sebagai berikut.

a. Inovasi Konsep Pemasaran

Ciri transformasi entrepreneur saat ini ialah adanya inovasi model penanganan dan pemasaran produk usaha. Hal ini dapat dilihat pada munculnya berbagai inovasi pemasaran yang dilakukan berbasis digital pada konsep olshop yang banyak digerakkan oleh kaum muda milenial. Model pemasaran melalui olshop berbeda dengan model bisnis secara konvensional, dapat pula dikatakan bahwa olshop merupaka jenis toko dunia maya yang menyediakan berbagai produk untuk menjawab kebutuhan konsumennya di dunia nyata.

b. Kecepatan Koneksi Teknologi

Teknologi merupakan investasi entrepreneur masa kini. Pelaku bisnis memaksimalkan penggunaan teknologi yang terkoneksi dengan internet untuk mempersempit jangkuan konsumen. Jika sebelumnya bisnis dilakukan dengan menempuh jarak menggunakan transportasi, saat ini segala sesuatunya sangat mudah dan supercepat. Bahkan, seorang entrepreneur yang mengembangkan bisnisnya cukup berada di rumah. Bentuk transformasi ini menuntut setiap individu untuk mengembangkan keterampilan dan pengembangan produk bisnis berbasis teknologi.

c. Ekonomi Pasar Bebas

Salah satu ciri penting transformasi entrepreneur era industri 4.0 ialah terciptanya ekonomi pasar bebas yang mendorong persaingan bebas pula. Diperlukan inisiatif yang penuh inovasi dalam menghadapi ekonomi pasar bebas. Seluruh jenis industri terhubungan dalam sektor pasar terbuka ini yang memungkinkan keterjalinan interaksi berbagai mitra secara cepat. Dengan 
demikian, setiap entrepreneur harus memperbaiki model komunikasi dan pembacaan peluang di era pasar bebas.

d. Peluang Otomatisasi

Otomatisasi merupakan ciri bawaan era industri 4.0 yaitu penggunaan mesin, sistem kontrol, dan sistem informasi untuk optimalisasi produksi industri. Otomasi dilakukan untuk mendorong percepatan kuantitas produksi dibandingkan dengan penggunaan tenaga kerja manusia. Di sisi lain, terdapat kemungkinan pemangkasan tenaga kerja manusia yang digantikan oleh mesin. Meskipun demikian, perubahan ini harus dipandang sebagai suatu yang optimis oleh entrepreneur sebagai peluang usaha di bidang perangkat mesin dan komputer. Era industri 4.0 tetap menjadi suatu kemajuan dan peluang kerja baru yang membutuhkan keterampilan khusus secara teknikal di bidang mekatronika, industri mekanik, teknik elektro maupun teknologi otomasi lainnya.

e. Kemudahan dan Efisiensi

Seluruh perubahan yang terjadi mendorong ke arah kemudahan dan efisensi menjangkau konsumen. Bagi entrepreneur, revolusi industru 4.0 membuka peluang pemasaran produk dan perbaikan kualitas layanan kepada konsumen. Adanya teknologi dunia digital akan mempersempit jarak antara seorang entreprenur dengan konsumennya. Pemasaran, penawaran harga, dan pembelian akan dilakukan dengan cepat. Kemudahan dan efisiensi ini juga menuntut tanggung jawab dan profesionalitas antara seorang entrepreneur dengan konsumennya.

Berdasarkan penjelasan di atas, dapat disimpulkan bahwa tranformasi entrepreneur bercirikan penggunaan teknologi informasi. Koneksi pengembangan wirausaha di era industri 4.0 sangat efisien menggunakan jejaring dunia digital yang terhubung dengan internet yang memangkas jarak antara entrepreneur dengan konsumennya. Semua kemajuan yang canggih tersebut mendorong inovasi dan adaptasi keterampilan yang kreatif untuk mengembangkan sektor bisnis yang dikembangkan.

\subsection{Penguatan Manajemen dan Strategi Entrepreneur Syariah}

Mencermati perubahan yang sementara berlangsung di bidang ekonomi dan bisnis global, seorang entrepreneur harus melakukan penguatan manajemen dan strategi. Penerapan manajemen dan strategi yang baik memungkin seorang pebisnis 
bertahan dalam perubahan yang terjadi, bahkan memungkin untuk menjadikannya menjadi pemenang pasar. Suatu manajemen bisnis memastikan seluruh komponen bisnis berjalan dengan baik serta sesuai dengan visi yang ingin dicapai. Hal penting perlu diperhitungkan dalam manajemen ini ialah orientasi pasar dan perkembangan teknologi. Teknologi telah memudahkan penerapan manajemen yang bisa dilakukan sebagai kontrol dimana saja seorang entrepreneur barada dapat mengendalikan perusahaan bisnisnya dari jaug.

Strategi juga tampak sangat dibutuhkan. Asumsinya dapat dipahami bahwa perubahan bisa terjadi dalam semua sektor wirausaha, namun setiap pengembang entrepreneur akan tetap membutuhkan strategi yang tepat. Zimmerer dan Scarbrough (2005: 162) merumuskan sembilan langkah proses perencanaan strategis yang bisa digunakan, sebagai berikut.

Pertama; melakukan pengembangan visi yang diterjemahkan menjadi misi yang bermakna dan fleksibel. Wirausaha yang baik mampu dan berhasil mentransmisi misinya kepada mitra maupun pada konsumen.

Kedua; lakukan penilaian kekuatan dan kelemahan perusahaan. Kekuatan dapat dipetakkan sebagai faktor internal yang secara positif dipandang potensial menjadi poin kapasitas bagi perusahaan bertahan. Sedangkan kelemahan merupakan faktor negatif internal yang potensial dapat melemahkan perusahaan yang dikembangkan.

Ketiga; Melakukan pengamatan terhadap lingkungan sekitar untuk mengetahui peluang dan ancaman yang dihadapi perusahaan.

Keempat; Mengidentifikasi faktor kesuksesan utama perusahaan yang berhubungan dengan hubungan antar variabel yang dapat dikendalikan menggunakan faktor penting yang berpengaruh terhadap kemampuan perusahaan dalam persaingan pasar.

Kelima; Analisis persaingan. Analisis ini akan memberikan informasi penting bagi entrepreneur terhadap pesaing bisnis yang dikembangkan. Analisis persaingan ini sangat perlu dilakukan secara positif yang memungkinkan jalinan kemitraan untuk pengembangan usaha secara menguntungkan.

Keenam; Penyusunan sasaran dan tujuan perusahan. Sasaran merupakan harapan yang ingin dicapai. Sedangkan tujuan harus dapat terukur dan mampu untuk dijangkau secara rasional berdasarkan jangka waktu tertentu yang bisa dievaluasi. Perubahan besar yang dapat terjadi sewaktu-waktu mengharuskan 
seorang entrepreneur merumuskan sasaran dan tujuan berdasarkan situasi-situasi mutakhir.

Ketujuh; Rumuskan opsi-opsi strategi dan memilih strategi yang tepat. Strategi ini menghimpun rencana permainan yang akan digunakan oleh perusahaan untuk mencapai sasaran dan misi yang telah dirumuskan. Perumusan ini perlu dilakukan secara terpusat pada berbagai faktor utama yang diidentifikasi.

Kedelapan; Menerjemahkan rencana strategus ke dalam rencana aksi. Semua perencanaan yang telah dilakukan tidak akan lengkap apabila belum dilakukan tindakan atau aksi konkrit sebagai bagian implementasi semua rencana yang ada. Dengan demikian, seorang entrepreneur selain melakukan berbagai perencanaan harus juga terus bergerak mengimplementasikan seluruh perencanaannya untuk mencapai misi perusahaan.

Kesembilan; Menentukan pengedalian yang tepat. Proses pengendalian merupakan kontrol yang harus dilakukan terhadap seluruh operasional perusahaan. Saat ini, teknologi memungkinkan kontrol dan pengendalian bisa dilakukan oleh seorang entrepreneur di mana saja berada dengan menggunakan teknologi berbasis aplikasi keungan dan lain sebagainya.

\section{Kesimpulan}

Berdasarkan penjelasan di atas, dapat disimpulkan bahwa entrepreneur merupakan kata yang dipadankan dengan istilah kewirausahaan. Secara teknis merujuk pada orang yang melakukan aktivitas wirausaha dengan berani mengambil berbagai resiko dalam pengembangan bisnis yang dilakukan. Dengan demikian, entrepreneur syariah ialah aktivitas wirausaha yang mengembangkan bisnis usaha dengan menerapkan prinsip nilai fundamental Islam.

Entrepreneur sangat bermanfaat mengembangkan individu secara mandiri. Beberapa manfaat diantaranya; berpeluang dan kebebasan mengendalikan nasib sendiri dan memberi peluang melakukan perubahan. Entrepreneur dalam Islam sangat dianjurkan dan dikelompokkan dalam masalah muamalah. Konsep yang berkaitan dengan masalah muamalah berhubungan dengan relasi yang bersifat horizontal manusia. Seluruh prosesnya dipertanggungjawabkan kelak di akhirat.

Era industri 4.0 telah mendorong entrepreneur bertransformasi dari sifatnya yang konvensional ke karakteristik yang lebih moderen. Ciri tranformasi ini dapat 
dilihat pada aspek inovasi konsep pemasaran, kecepatan koneksi teknologi, ekonomi pasar bebas, peluang otomatisasi, dan kemudahan dan efisiensi. Bentuk transformasi tersebut ke erah yang lebih cepat dan masif, sehingga seorang entrepreneur harus melakukan penguatan manajemen dan strategi dalam pengelolaan bisnisnya.

\section{DAFTAR PUSTAKA}

Abdullah, Ma'ruf. 2011. Wirausaha Berbasis Syariah. Banjarmasin: Antasari Press.

Basrowi. 2011. Kewirausahaan untuk Perguruan Tinggi. Bogor: Ghalia Indonesia.

Kasmir. 2006. Kewirausahaan. Jakarta: PT RajaGrafindo.

Suryana, Yuyus dan Bayu, Kartib. 2010. Kewirausahaan: Pendekatan Karakteristik Wirausahawan Sukses. Jakarta: Kencana Prenada Media Group.

Zimmerer, T.W dan Scarbrough, Norman. 2005. Kewirausahaan dan Manajemen Bisnis Kecil. Jakarta: Erlangga. 